\title{
La categoría Sistema Representativo y su re-presentación y recepción en el discurso político de las minorías reflexivas rioplatenses (1816-1827)*
}

\author{
Rubén Darío Salas \\ Universidad Nacional del Sur, Bahía Blanca, \\ y Universidad de Buenos Aires, Argentina
}

\begin{abstract}
El presente ensayo, privilegia de igual modo el objeto de estudio (Sistema Representativo) y el método (histórico-semántico desde la perspectiva del análisis del discurso). Nuestro objetivo persigue enfrentar el objeto de estudio, atendiendo a la re-presentación que del mismo se hacían las minorías reflexivas rioplatenses, y hacerlo a través del análisis del discurso histórico-político por ellas producido. Como resultado de la investigación, este estudio, al poner en relación el objeto -Sistema Representativo- con el órgano conceptivo de esa realidad — discurso - accede, desde tal perspectiva, a la decodificación del mismo, ofreciendo una exégesis del discurso que descubre el sentido de sus signos dentro de su contexto histórico. Nuestra investigación atendió, respecto de nuestro objeto de estudio, al análisis de fuentes - específicamente periódicos de la época y Actas de los Congresos Constituyentesy, respecto del método elegido, a los trabajos bibliográficos relacionados con el análisis del discurso en general y con el análisis del discurso histórico-político, en particular.
\end{abstract}

\section{Introducción}

Si bien este ensayo toma como objeto de estudio un tema de historia de las ideas y de las instituciones políticas —el Sistema Representativo-, privilegia también el método con que se procede a su abordaje, por estimar que permite una visión menos impresionista de esa realidad. Tal objeto de estudio lo afrontamos siguiendo la re-presentación que se hacían las minorías reflexivas rioplatenses, a través del análisis de su discurso político, entendiendo por discurso "un proceso estructurante de significación"; el "lugar de la contextualización". ${ }^{2}$ Buscamos estudiarlo atendiendo a los

* El tema aquí abordado, reestructurado y adaptado en esta instancia, formó parte de un trabajo más amplio, motivo de una tesis doctoral (inédita), concluida en el año 1994, sobre el tema El dilema Monarquía-República en el Río de la Plata (1816-1827): una interpretación desde el análisis del discurso, cuya dirección estuvo al cuidado del Prof. Dr. Víctor Tau Anzoátegui. pág. 10 .

1 Da Silva, Anazildo Vasconcelos: Semiotizaçao literária do discurso, Rio de Janeiro, 1984,

2 Maingueneau, Dominique: Introducción a los métodos de análisis del discurso, Buenos Aires, 1980, pág. 16. 
códigos que su cultura nos impone, articulando el Sistema Representativo con el discurso y, desde tal perspectiva, descubrir el sentido de sus signos ${ }^{3}$ dentro de su contexto. En suma, método histórico - conceptualizante- de raíz lingüística —análisis del discurso- ${ }^{4}$ es decir, enfoque interdisciplinario histórico-semántico, histórico por su objeto y lingüístico por su método.

A través del análisis del discurso perseguimos demostrar que el proceso de selección de un sintagma o de un lexema, por parte de las minorías reflexivas, nada tiene de azaroso o arbitrario.Durante el período estudiado se acuñaron "conceptos", en tanto respuesta al "destino" de una sociedad concreta y no como simple remedo de otra realidad, conformándose osados 'discursos-tipo', que permiten identificar sendos proyectos de sociedad (de signo monárquico o republicano, en una instancia, unitario o federal, en otra).

"Precisar" y "rectificar" constituyen la base del pensamiento dinámico y, de suyo, lo alejan de las seductoras uniformidades, ${ }^{6}$ siempre peligrosas, aún más cuando se producen las aceleraciones de la historia que, para el caso específico del vocabulario político, el siglo XVIII traduce en violentos desplazamientos semánticos a través del envilecimiento y ennoblecimiento de lexemas y sintagmas, para todo lo cual la realidad indiana ofrece, además, perspectivas singulares. En este sentido y, atentos a nuestro objeto de estudio, observaremos que el mismo, en la misma época, coincide en tanto significante, pero difiere en su significado, ${ }^{7}$ lo cual nos inclinó a introducir una taxonomía (Sistema Representativo Ortodoxo e Imperfecto) para encuadrar las re-presentaciones que se hacían de éste las élites rioplatenses.

¿Por qué la secuencia de 1816 y 1827 ? En virtud de la relevancia que el debate sobre las modalidades gubernativas (expresiones del Sistema Representativo) alcanza en el Congreso de Tucumán; intensidad y hondura que éste retoma durante las sesiones del Congreso Constituyente de 1824-1827.

3 Foucault, Michel: Las palabras y las cosas. Una arqueología de las ciencias humanas, Buenos Aires, 1968, pág. 38.

4 Véase Veyne, Paul: "La historia conceptualizante", en Jacques Le Goff y Pierre Nora, dir., Hacer la Historia, Barcelona, 1978, v. I, págs. 75-91; Lavandera, Beatriz R.: Curso de Lingüística para el análisis del discurso, 1990, págs. 12-15, 25-27, 33 y 48.

5 Sartori, Giovanni: Teoría de la democracia, Buenos Aires, 1990, t. II, págs. 328 y 331.

6 Bachelard, Gastón: La formación del espíritu científico. Contribución a un psicoanálisis del conocimiento objetivo (1948), Buenos Aires, 1972, pág. 19.

7 Véase sobre signo, significado y significante: Saussure, Ferdinand de: Curso de lingüística general, ap. José Sazbón, comp.: Saussure y los fundamentos de la lingüística, Buenos Aires, 1977, págs. $85 \mathrm{y}$ sigs. 


\section{Las minorías reflexivas rioplatenses y el Sistema Representativo}

\section{Constitucionalismo y Legitimidad}

¿Sobre qué marcos de referencia institucional operaban estas minorías? El marco de referencia lo proporciona Europa occidental, donde pujan dos modelos institucionales antagónicos, reflejo de dos concepciones de vida radicalmente diferentes.

Por un lado, el "sistema representativo" británico, cuyo modelo de Gobierno mixto será el substratum de otro que, modificado sustancialmente, pero fusionado con él — la Revolución Francesa- bautizará como Monarquía Constitucional, elevado a categoría teórica por el Curso de política constitucional.

Este paradigma — modalidad monárquica de lo que llamaremos Sistema Representativo Ortodoxo — supone el eclipse de la forma Monarquía $\mathrm{y}$, por ende, y en su calidad de corporaciones, del clero y la nobleza, que son sus pilares.

Tal paradigma, que la ciencia política llamaría Monarquía Parlamentaria, no era conocido con ese nombre en la presente coyuntura. El sintagma Gobierno parlamentario ${ }^{8}$ se usaba ocasionalmente como sinónimo de Sistema representativo en sentido lato, tanto para designar una Monarquía temperada (con monarca responsable), para designar el paradigma más tarde denominado presidencialista — según la invención institucional norteamericana-, como para calificar el modelo de monarca "neutro" de Constant. Depositada la soberanía en la representación, el monarca deviene irresponsable, "neutro", conforma, afirma Constant, un "cuarto poder", recayendo el Poder Ejecutivo en un Gabinete responsable ante la autoridad de las Cámaras. Es decir, poder residuario del monarca y omnipotencia legislativa. Si bien no se oculta la contradicción teórica entre el modelo de Gobierno Mixto y el de Monarquía Constitucional con monarca "neutro", el segundo absorberá el carácter arquetípico del primero; arquetipo vertebrador de cualquier modalidad de Sistema Representativo, sea imperfecto u ortodoxo: no se puede concebir éste sin aquél. En tal sentido, ya las primeras constituciones escritas (norteamericana y fran-

8 El sintagma "Gobierno Parlamentario" lo encontramos en El Censor (1815-1819). Reimpresión facsimilar. Semanario de Buenos Aires, en Biblioteca de Mayo (en adelante BM), Buenos Aires, 1960-1963. N. ${ }^{\circ}$. 81, 3 de abril de 1817; n. ${ }^{\circ} 91,12$ de junio de 1817; n. ${ }^{\circ}$ 93, 26 de junio de 1817, t. VIII, págs. 7032, 7096, 7107. 
cesa), reproducían los principios básicos del paradigma británico, pues ambas se conformaban sobre el principio de la división del poder. Pero, en tanto la primera, gesta un segundo paradigma de Sistema Representativo Ortodoxo, pues construye su Gobierno mixto con poderes absolutamente electivos, otorgando un papel protagónico al Poder Judicial y acentuando la separación de las ramas del poder, la segunda, distorsiona el concepto de Gobierno Mixto, al estructurar la rama legislativa con una sola Cámara; convirtiéndose en la primera expresión de Sistema Representativo Imperfecto.

Frente al paradigma del Estado liberal se opone el modelo del legitimismo, representado por la Santa Alianza. Ante el constitucionalismo, voz que evocaba para las Monarquías continentales la subversión institucional, el legitimismo rescataba los fundamentos de la autoridad regia tradicional, la alianza santa Trono-Altar, y todo lo que evocara el acervo tradicional.

Las élites rioplatenses que, con mayor o menor fidelidad, se adherían al ideario liberal e ilustrado, como sus pares europeos, identificarían en su discurso legitimismo con Monarquía Absoluta, integrando un campo léxi$\mathrm{co}^{9}$ cuyo eje era: Gobierno despótico. El sintagma Monarquía absoluta aparecía como cómodo estereotipo léxico, tanto para calificar a todo régimen monárquico que ofrecía resistencia al dogma liberal, aun cuando, en rigor, tal régimen había concluido su existencia en Europa Occidental, como para argumentar acerca de las bondades del paradigma británico. Lo cierto es que la Monarquía Constitucional que asomaba en Europa Occidental, resultaba una adaptación del legitimismo monárquico, temperado por la introducción del principio de la división del poder acuñado en una carta constitucional.

\section{Teoría y praxis}

En la región rioplatense, la forma de gobierno representativa aparece en las primeras propuestas de organización del Estado, sistematizadas por

9 Empleamos la expresión "CAMPO LÉXICO" y, su equivalente en el plano del contenido, “CAMPO SEMÁNTICO”, como sinónimos, para referir a lexemas y sintagmas que, por pertenecer a un mismo campo, se encuentran relacionados e integrados dentro de un sistema lingüístico. Cada “CAMPO LÉXICO” lo entendemos integrado por uno o más lexemas o sintagmas que actúan como "eje". (Véase Vallejos de Llobet, Patricia: El léxico intelectual en el español bonaerense de principios del siglo XIX, Bahía Blanca, 1990, págs. 15 y sigs.). 
Mariano Moreno..$^{10}$ En este sentido, tanto los proyectos constitucionales de 1813, como el Estatuto de 1815, el Reglamento Provisorio de 1817 y las Constituciones de 1819 y de 1826, se vacían en los moldes del Sistema Representativo. ${ }^{11}$ Importantes sectores de las minorías reflexivas rioplatenses recurren al paradigma que la literatura política liberal difundía y lo vuelcan en los documentos mencionados, aun cuando no ignoraran que tanto Juntas y Triunviratos como Directorios sólo rendían culto externo a la normativa racional, descansando su existencia, efectivamente, en la fuerza militar. ${ }^{12}$

Producida la crisis de 1820, muchas voces se alzan advirtiendo que, por ser el Sistema "más perfecto", grandes eran las dificultades para su implementación. El periódico porteño El Centinela explica que, ni aún en Buenos Aires, donde tanto se escribió en su favor, goza "de una opinión general" ${ }^{13}$ subrayando que las provincias, aun no poseyendo "un sistema ordenado de principios", ${ }^{14}$ lo adoptan instintivamente o influidas por el espíritu del siglo. ${ }^{15}$

Julián S. de Agüero llamó a no equivocarse con lo observado en pueblos ya constituidos, en donde el gobierno se encontraba establecido, pues si ellos estaban disconformes con el Poder Ejecutivo, trabajaban para reducirlo a los límites legales, en tanto encuentran el basamento que otorga "el prestigio y la ilusión que tienen los reyes de la Monarquía Constitucional" ${ }^{16}$ En el Río de la Plata se trataba de establecer el Gobierno sin tener a la mano ninguno de los materiales que se ofrecían en Europa, pues no

10 Moreno, Mariano: "Sobre la misión del Congreso convocado en virtud de la resolución plebiscitaria del 25 de mayo”, en M. Moreno: Escritos políticos y económicos, Buenos Aires, 1915, págs. 277 y sigs.

11 Colautti, Carlos E.: Proyectos constitucionales patrios, 1811-1826, Buenos Aires, 1983, págs. 11-120.

12 "Los nuevos gobiernos [...] dependen del capricho de tres o cuatro jefes militares a los que con degradación tienen que contemplar y adular". ("Carta de San Martín a Guido", París, 1 de febrero de 1834, en Documentos del Archivo de San Martín, Buenos Aires, 1912, v. VI, pág. 568).

13 "Revoluciones. Correspondencia. Uniformidad de opinión [...]", El Centinela (1822-1823). Reimpresión facsimilar. Semanario de Buenos Aires, en BM, n. ${ }^{\circ} 68,9$ de noviembre de 1823, t. IX -2. ${ }^{a}$ parte—, pág. 8976.

14 El Nacional (1824-1826). Reimpresión facsimilar. Semanario de Buenos Aires, en BM, n. ${ }^{\circ} 15,31$ de marzo de 1825 , t. X, pág. 9456.

15 El Nacional, n. ${ }^{\circ}$ 10, 24 de febrero de 1825, t. X, pág. 9391. Véase también sobre las ventajas del Estado Representativo, El Correo de las Provincias (1822-1823). Reimpresión facsimilar. Semanario de Buenos Aires, en BM, n. ${ }^{\circ}$ 16, 3 de abril de 1823, t. X, pág. 9265. Sobre el lexema "República" como sinónimo de Estado representativo: El Centinela, n. ${ }^{\circ} 12,13$ de octubre de 1822, t. IX -1. a parte-, pág. 8098.

16 Sesión 42 del 11 de junio de 1825, en Asambleas Constitucionales Argentinas (en adelante, ACA), v. II, pág. 30. 
existía situación similar a la de Iberoamérica "ni en pueblo Antiguo ni Moderno". ${ }^{17}$

Entusiasta del Sistema Representativo, pero también consciente de la realidad social rioplatense, el ministro Bernardino Rivadavia, decidió incursionar en la pedagogía política. Fue entonces cuando encargó al deán Funes la traducción de la obra Ensayo sobre las garantías individuales, escrita en 1818 por el publicista francés Pedro C. F. Daunou, aparecida en Buenos Aires en los primeros meses de 1822. Una intención admonitoria inclinó a Rivadavia hacia esta obra. En ella, Daunou enumeraba las cualidades que debían adornar a toda sociedad que aspirara a vivir bajo un Sistema Representativo. Su discurso rezumaba ambiciosos presupuestos, más aún si habían de implementarse en un ámbito donde mediaba un abismo entre la teoría y la praxis política y en el cual, además, todo proyecto de sociedad chocaba con furiosas ambiciones de facción y la absoluta indiferencia de los gobernados. El Sistema fracasa, apuntaba Daunou, cuando la "disposición general de ánimo" es compulsivamente adicta a los cargos públicos y la "masa de gobernados" escéptica respecto del mantenimiento de las "garantías individuales" y del "sistema representativo instituido para defenderlas". ${ }^{18}$

\section{Concepto}

Nación libre es la que se gobierna por un Sistema Representativo y éste existe donde se encuentra "una forma de gobierno establecida en la cual aparezcan deslindados los poderes, marcadas sus atribuciones y el modo de ejercerlas". Cuando esto se da, estamos frente a "la forma Representativa Republicana", ${ }^{19}$ cuyas "bases firmes" son "la Independencia, la Libertad y la Ilustración". ${ }^{20}$

Manuel A. de Castro, Valentín Gómez y demás miembros de la Comisión constituyente del Congreso de 1824-1827, al presentar el "Proyecto" sobre la forma de administración más conveniente, consideran que el Sistema Representativo o su sustituto léxico más extendido, Gobierno

17 El Nacional, n. ${ }^{\circ} 3,6$ de enero de 1825, t. X, pág. 9318.

18 Daunou, Pedro C. F.: Ensayo sobre las garantías individuales (1818). Traducción del francés con "Notas" explicativas y aclaratorias por el Dr. D. Gregorio Funes (1822). Buenos Aires, 1941, págs. 110 y 120.

19 Véase El Nacional, n. ${ }^{\circ} 9,17$ de febrero de 1825, t. X, pág. 9386. pág. 8.598

20 "Tercera Legislatura", El Centinela, n. ${ }^{\circ} 42,11$ de mayo de 1823, t. IX -2." parte-, 
Libre, es obra de tres grandes descubrimientos: las asambleas representativas del pueblo, que reemplazan a las colectivas y tumultuarias; la separación y deslinde de los tres poderes y la balanza con que deben contrapesarse las cámaras legislativas. ${ }^{21}$

\section{La Naturaleza Republicana}

En estricta teoría, la mención de la categoría política que nos ocupa remite a dos sintagmas sinónimos, a saber: Sistema Representativo o Sistema Representativo "Republicano", adjetivo calificativo que refuerza semánticamente la naturaleza electiva de la nueva forma de gobierno. Por tanto, dentro de una estructura sintáctica así definida, para nada alude lo republicano a la categoría clásica República o Democracia, pues supone tanto a la República liberal como a la Monarquía Constitucional, dada la estructura mixta del Sistema que disuelve las categorías políticas tradicionales.

Nos importa señalar que el "discurso-tipo" de 1816-1820 planteó al Sistema Representativo casi exclusivamente como dicotomía MonarquíaRepública, en tanto, luego de 1820, si bien ésta se estableció entre UnidadFederación, no lo hizo de manera excluyente pues, las élites enroladas en la corriente constitucionalista-liberal, con empatía monárquica y fidelidad principista, emplearon como estrategia discursiva, aludir a las bondades del Sistema Representativo, argumentando que, en tanto un Gobierno sea libre, no importa la modalidad que adopte, pues Monarquía Constitucional o República "sólo son aparentemente contrarios". ${ }^{22}$

En este sentido, el "Proyecto" citado, luego de ponderar el buen sistema constitucional de Gran Bretaña y de América del Norte, expresa: "Sólo las FORMAS MIXTAS convienen a las sociedades modernas; porque, separando los vicios de cada una, acumulan las bondades de todas". ${ }^{23}$

Cuando se trató en el Congreso General Constituyente de 1816-1820 el proyecto de coronación en el Río de la Plata del duque de Luca, el Congreso impuso como " 4 . $^{\text {a }}$ condición" que las Provincias "reconocerán por su monarca al Duque de Luca bajo la Constitución política que tienen

21 Sesión del 14 de julio de 1826, en ACA, v. III, pág. 215. Pazos Silva —redactor del periódico La Crónica Argentina (1816-1817) — al hablar de los "inventos institucionales" desde la época de Licurgo, se expide en idénticos términos. Reimpresión facsimilar. Semanario de Buenos Aires, en BM, n. ${ }^{\circ}$. 31, 14 de diciembre de 1816, t. VII, págs. 6412-s..

22 "Observaciones al n. ${ }^{\circ} 74$ del diario brasilense", El Argos, n. ${ }^{\circ} 42,24$ de mayo de 1823, v. III, pág. 172.

23 Sesión del 14 de julio de 1826, en ACA, v. III, pág. 215. 
jurada: a excepción de aquellos artículos que no son adaptables a una forma monárquica hereditaria". ${ }^{24}$ Lo expresado denota la poca distancia que, dentro del Sistema Representativo, existe - cuando de naturaleza y estructura de Gobierno Mixto se habla - entre una modalidad absolutamente electiva y otra que privilegie el componente hereditario, de igual manera que una cuidadosa decodificación del discurso advierte sobre el carácter estrictamente mixto y no monárquico de la Constitución de 1819.

Las minorías reflexivas dirigen su atención fundamentalmente hacia dos modalidades de Sistema Representativo, el Gobierno Mixto - también llamado Monarquía Constitucional- de Gran Bretaña, y, en menor medida, el Gobierno Mixto Republicano, experimentado en los Estados Unidos de América del Norte, este último examinado con mayor atención después de la crisis de 1820, específicamente la estructura de su Poder Ejecutivo, en tanto observan que en Estados Unidos no han hecho "más que poner un PRESIDENTE en lugar de un REY". ${ }^{25}$

Tal examen - de rigor por tratarse de arquetipos constitucionales- se confunde dentro del discurso con menciones que se alejan de los arquetipos indicados, por ejemplo, cuando se toma como fuente la Constitución de Cádiz o la Carta francesa. Importa advertir que, quienes redactaron los Proyectos constitucionales de 1819 y de 1826 , si bien realizaron un prolijo examen de los paradigmas mencionados y se mantuvieron dentro de sus cánones, dieron a su propuesta un enfoque singular.

Es a la naturaleza republicana del Sistema Representativo que se refiere Juan I. de Gorriti cuando, para acallar las voces que estimaban declarada la forma de gobierno atento el juramento pronunciado por los diputados en 1824 al incorporarse al Congreso, acota que es cierto que se ha "jurado sostener la forma de Gobierno republicana bajo un sistema representativo" pero, se pregunta: “ ¿Cuál es la forma de gobierno representativo que no sea republicano? La forma monárquica, siendo representativa, es republicana". ${ }^{26}$ Como afirma Agüero, "todos los gobiernos que son monarquías moderadas tienen mucho de republicano", pues el carácter representativo de sus Cámaras es lo que define a la República. ${ }^{27}$

El discurso de las élites rioplatenses, al re-presentarse institucionalmente el Sistema Representativo, acentuará los principios básicos que con-

\footnotetext{
24 Sesión Secreta del [...] 12 de noviembre de 1819, en ACA, v. I, pág. 577.

25 El Centinela, n. ${ }^{\circ}$ 51, 13 de julio de 1823, t. IX -2. ${ }^{a}$ parte-, pág. 8718.

26 Sesión 25 del 14 de abril de 1825, en ACA, v. I, pág. 1247.

27 Sesión 41 del 9 de junio de 1825, en ACA, v. II, pág. 26.
} 
forman su campo léxico: división del poder; elección; publicidad. Todo Gobierno Libre se levanta sobre dos principios fundamentales: "independencia [y] armonía entre los poderes", afirma Valentín Gómez. ${ }^{28}$

Los diputados del Congreso de 1816-1820, al referir al sistema de representación por el procedimiento electoral, nos ofrecen el discurso-tipo de la época estudiada, afirmando que tal sistema, único digno de "Pueblos libres", sustituye "a las reuniones en masa", que para diferentes asuntos de "utilidad común", implementaban "los pueblos libres de la Antigüedad". ${ }^{29}$

Respecto de la publicidad, acotan los editores de El Argos, que allí donde el Sistema Representativo se encuentre establecido "en toda su extensión, no puede faltar la publicidad" de los actos de gobierno, pues constituye el único medio por el que "los representados se instruyen de la lealtad con que sus representantes" en el Poder Ejecutivo "llenan los deberes". ${ }^{30}$

\section{Arquetipos y modelos teóricos}

Antes de abordar específicamente el tema del acápite nos importa precisar, respecto de la estructura de los "discursos-tipo" referidos en este ensayo que, si bien todo discurso es argumentativo, en la época lo es de manera superlativa, predominando los componentes descriptivos, didácticos y prescriptivos del mismo. Generalmente el locutor aparece distanciado de su enunciado y lo plantea como acto de verdad colectiva. De naturaleza neoclásica, el discurso no se aparta demasiado del modelo de la Retórica, en el cual la argumentación surge de la aplicación de una técnica exterior al discurso, suponiendo un determinado efecto persuasivo en el destinatario, ${ }^{31}$ por otra parte, concebido como receptor pasivo.

Es nuestra intención evitar cualquier anarquía léxica; por tanto, y atendiendo a la estructura discursiva de la época, elegimos el lexema "arquetipo" para designar al Sistema Representativo, y "modalidad" para referir al carácter ontológico del arquetipo. Las "modalidades" que lo tipifican remiten a dos paradigmas: Monarquía, expresada por la modalidad

28 El Argos, n. ${ }^{\circ}$ 141, 20 de abril de 1825, v. V, pág. 136.

29 Sesión del 21 de agosto de 1818 , en ACA, v. I, págs. 373-s..

30 El Argos, n. ${ }^{\circ} 179,20$ de agosto de 1825, v. V, pág. 283.

31 Véase García Negroni, María M., y Zoppi Fontana, Mónica G.: Análisis lingüístico y discurso político. El poder de enunciar, Buenos Aires, 1992, págs. 21-22, 29-32, 53. 
Gobierno mixto británico o Monarquía Constitucional con monarca "neutro", y República, por la modalidad Gobierno mixto norteamericano o República democrática.

En relación con el arquetipo y las modalidades enunciados, hablaremos de modelo teórico, ${ }^{32}$ para referir a aquellas modalidades que, dada su estructura específica difieren, strictu sensu, de los paradigmas. Sirva, a manera de ejemplo, la Constitución francesa de 1791, la de Cádiz de 1812, o los modelos locales, como las Constituciones de 1819 y 1826.

La teoría política contemporánea, al conceptualizar el arquetipo Sistema Representativo del primer tercio del siglo XIX ofrece una visión en extremo generalizadora, impidiendo advertir que, para la época, dentro del mismo arquetipo, se encuadraban modelos teóricos, a veces muy disímiles entre sí y respecto de las modalidades paradigmáticas. Esta variedad de modelos teóricos aparece con claridad en la re-presentación que de los mismos hacen las élites rioplatenses.

Atendiendo a razones estrictamente metodológicas nos referiremos a Sistema Representativo Ortodoxo y Sistema Representativo Imperfecto; deslinde que atiende a subrayar las diferencias que se observan en los modelos teóricos, las cuales, en muchos casos, son consignadas en la época imprecisamente.

Damos el nombre de Sistema Representativo Ortodoxo a aquél que se identifica con los paradigmas políticos (británico y norteamericano), y encuadramos bajo el nombre de Sistema Representativo Imperfecto aquellas modalidades cuyos modelos teóricos poseen una estructura que se aparta parcialmente de los respectivos paradigmas. Excepción hecha de los paradigmas, no abunda el discurso político de las élites rioplatenses en reflexiones medulosas sobre los distintos modelos teóricos. Se pondera sí la Carta francesa de 1814, por su flexible estructura, logra articular las exigencias de sectores liberales y tradicionalistas; modelo que permitía un acercamiento al paradigma británico, sin abandonar premisas básicas del legitimismo. En orden decreciente, se examinan los modelos temporalmente cercanos, vigentes o no, como el español, el portugués y el de Baviera. Así los lineamientos generales de la Carta, aunque con un énfasis mayor puesto en el carácter histórico-tradicional, se advierten en los modelos teóricos de la Constitución de Baviera y, en la misma línea, en la de Portugal, nacida al derogarse la Constitución inspirada en los principios de la de Cádiz, ésta

32 Ferrater Mora, José: Diccionario de Filosofía, Buenos Aires, 1975, s.v., modalidad, tipo, modelo. 
última, obra del liberalismo doctrinario español. El discurso ofrece dos lecturas: descriptiva de la organización estamental de las Cámaras y, en su repliegue, persuasiva, en tanto busca advertir sobre la necesidad de priorizar la realidad histórica cuando se aceptan formas nuevas.

Respecto de la llamada "forma de administración" (centralizada o no), podemos afirmar, siguiendo la taxonomía inaugurada por Alexis de Tocqueville luego de 1830 que, en tanto el modelo constitucional se encuadrara en el concepto del tradicionalismo-histórico, se imponía un amplio grado de descentralización espacial, el que quedaba reducido considerablemente si se aplicaba la teoría constitucionalista liberal o concepto racionalnormativo, es decir, si el concepto de Estado-Nación triunfaba sobre el de Estado-Región. ${ }^{33}$

Importa precisar que los lexemas centralización y descentralización, están casi ausentes en el vocabulario de la época, cuando se alude a las distintas formas de administración del Estado. Lo mismo ocurre en el ámbito rioplatense, donde las voces "consolidado o concentrado" y su antónimo "federal", parecen reflejar más acertadamente ambos conceptos. En resumen, tanto centralización como su contrario, no resultaban voces ilustrativas en el léxico político de la época: carecían de significación ideológica, en tanto no se ajustaban adecuadamente para referir a cuestiones gubernativas ni a representaciones espaciales.

Los modelos rioplatenses se encuadran dentro de un Sistema Representativo Imperfecto: de ellos prestaremos atención, dada la envergadura teórica que revisten, a las Constituciones de 1819 y de 1826.

\section{Constitución de 1819}

Ésta toma "las principales ventajas de los gobiernos monárquico, aristocrático y democrático evitando sus abusos"; lo electivo en distinto grado condensa lo aristocrático y lo democrático, al tiempo que rescata de la monarquía sus principios sustanciales: la unidad que da a los planes, la celeridad de la ejecución, el vigor, la energía. ${ }^{34}$

¿Establece la Constitución de 1819 como forma de gobierno una República o una Monarquía Constitucional?: establece un Gobierno mixto.

33 Véase M. García Pelayo: Derecho..., págs. 33-44 y A. de Tocqueville: La democracia en América, Madrid, 1984, v. I, págs. 97-108; Enciclopedia Internacional..., v. II, págs. 258-s..

34 Sesión del 31 de agosto de 1818, en ACA, v. I, pág. 376. 
Como lo apunta el deán Funes en el Manifiesto explicativo de la Constitución, ésta es "un estatuto que se acerca a la perfección: un estado medio entre la convulsión democrática, la injusticia aristocrática y el abuso del poder ilimitado". ${ }^{35}$

Más allá de motivaciones políticas que hubieran incidido para no encuadrar la categoría Gobierno mixto dentro de los rótulos República o Monarquía Constitucional (insustanciales para el concepto de Sistema Representativo), omitiendo la sección "Forma de gobierno" del texto, lo cierto es que la designación resulta de absoluta ortodoxia teórica y solidaria con el entramado del discurso, que guarda una total unidad léxica. Tal como surge del Manifiesto que acompaña la Constitución, los autores del proyecto constitucional exhibieron coherencia doctrinaria con la modalidad adoptada. Si el modelo constitucional respondía a una estructura mixta, imponer otro nombre importaba debilitar, en rigurosa teoría, la arquitectura del mismo. Acaso en la prestigiosa constitución norteamericana la definición de la forma de gobierno no resultaba incidental, sólo aludida una vez en la Secc. 4 y última, careciendo de total relevancia.

En la Constitución de 1819 puede apreciarse el carácter cuasi-estamentario o, más precisamente, sectorial, en la composición del Senado, contrariamente a la representación individual como exigía el Sistema Representativo Ortodoxo.

Los autores del Proyecto Constitucional de 1819 — destacados juristas, como Juan J. Paso y Antonio Sáenz, entre otros- explican la intencionalidad que los condujo a la conformación del Poder Legislativo. Así como se determinó que los representantes fueran "del fuero común", se estimó imprescindible que la Cámara de Senadores reprodujera, aunque fuera imperfectamente, la Cámara de los Pares británica. Las decisiones adoptadas se fundamentaron en la forma mixta ${ }^{36}$ del Proyecto Constitucional, teniendo presente la necesidad de encuadrarlo dentro de un modelo absolutamente electivo, recordando que se hacía necesario "aplicar la constitución inglesa en nuestro continente del modo que la pueda recibir". ${ }^{37}$

El texto producido por los constituyentes fue el homenaje póstumo a la Monarquía española, entendida bajo la luz del tradicionalismo ilustrado y, en esa línea, dicho homenaje rinde un culto más bien externo al espíritu

35 Funes, G.: Manifiesto..., en ACA, v. VI -2. a parte-, pág. 725.

36 Sesión del 31 de agosto de 1818, en ACA, v. I, pág. 376.

37 El Independiente, n. $^{\circ}$ 2, 22 de septiembre de 1816, t. IX -1. a parte-, pág. 7740. 
del siglo para rescatar en todo lo posible la fuerza de la tradición, es decir, aquellas formas primarias que el imaginario social conserva latentes, reveladoras de la ley interior del discurso. ${ }^{38}$ Homenaje al régimen venerado, saturado, prototípico, y a la nobleza como sentida carencia, aquel estamento (genuino equilibrador del Estado) que no debe su origen a la casualidad ni al capricho; estamento que, increíblemente, apunta Manuel A. de Castro, han dejado de lado los constituyentes de Cádiz para conformar las Cortes, cuando en tierras rioplatenses, por carecer de él, hubo que hacer el esfuerzo de inventar algunos. ${ }^{39}$

\section{Constitución de 1826}

Sus autores producen un modelo teórico inspirado en la Constitución de 1819. Pero, obligados por circunstancias políticas derivadas de la crisis de 1820 y no, en menor medida, por replanteos teóricos demostrativos de las ventajas a obtenerse por la desaparición de la numerosa representación provincial, acordaron dejar de lado el Senado cuasi-estamental, guiándose por los lineamientos del paradigma estadounidense.

La eliminación del Senado corporativo producía un doble efecto: por un lado le quita protagonismo efectivo al principio aristocrático, al perder el Senado el vigor y poder de decisión que, por su naturaleza, proporcionan las organizaciones corporativas. La tarea posterior consistirá en reestructurarlo sobre otras bases. Por otro, en tanto las corporaciones son exponentes de las distintas clases sociales, se obstruía el puente que acercaba los intereses sectoriales operantes en cada una de las Provincias. Eliminada en la Constitución de 1826 la forma de representación con mandato imperativo, se destruye la organización cuasi-confederal a la que está ligada, quedando la representación en manos de individuos que no responden a corporación alguna y que, a su vez, se consideran desvinculados de sus representados — base del Sistema Representativo Ortodoxo-. Éstos representan los intereses de la Nación — concepto racional-normativo- y no los de sus respectivas Provincias o Pueblos — concepto tradicional-histórico o contractualista-.

38 Foucault, M.: Las palabras..., pág. 5.

39 El Argos, n. ${ }^{\circ}$ 19, 14 de agosto de 1821, v. I, pág. 120; El Independiente (1815). Reimpresión facsimilar. Semanario de Buenos Aires, n. ${ }^{\circ}$ 3, 24 de enero de 1815, Periódicos de la época de la Revolución de Mayo. Buenos Aires, 1961, v. IV, pág. 83. 
La idea de Estado-Nación se identifica con un vigoroso centralismo político-administrativo que, a su vez, conduce a un aumento gradual de la centralización espacial. En tanto, el concepto de Estado de base contractual, que se encuentra en los cimientos del Imperio ibérico, alterna el vigoroso centralismo político con una acentuada descentralización espacial, de manera elocuente reflejada en el enfoque casuista del Derecho, apenas conmovido, en la praxis, con el advenimiento de la Casa de Borbón. ${ }^{40}$

La teoría del discurso, entendida como teoría del conocimiento, ${ }^{41}$ y la consiguiente decodificación de los textos, permite también advertir, respecto del Poder Judicial que, si bien los autores de la Constitución de 1826 lo diseñan sobre la base del texto estadounidense, no hacen de éste el eje del sistema, como lo es en la Constitución de 1787. En tal sentido, el énfasis del discurso se continúa colocando en el paradigma británico, de allí que el principio aristocrático dé el tono a la Constitución. Desaparecido el Senado corporativo, se busca fortalecer dicho principio avanzando sobre la Cámara de Diputados, debilitando el principio democrático de que se nutre.

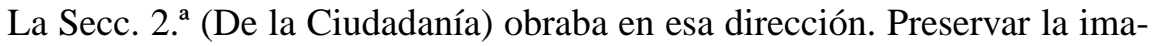
gen del orden monárquico surgía como un imperativo de la hora, sobre todo cuando los efectos deletéreos de la extinción de la Monarquía se hacían inocultables; la consigna era restaurar el espíritu de aquel orden, algo de su ley interior, de su carácter inmutable. Ateniéndonos al sentido tradicional de la voz federal, la representación corporativa de la Constitución de 1819 suponía tal carácter, en tanto cada Provincia disponía de una significativa presencia, expresada en diputaciones sectoriales con mandato imperativo. Respecto del Senado, para la Comisión redactora de la Constitución de 1826, dicha composición de manera alguna compensaba el prestigio que a una Monarquía otorga el monarca hereditario quien, por lo mismo, podía actuar como árbitro y fuerza conciliadora, lo cual jamás podría darse en un régimen cuya suprema magistratura residía en una figura electiva, y de suyo afectada siempre por intereses de clase y pasiones. Es por ello que en la nueva Constitución se insistirá en otorgar al principio aristocrático una base mas extensa y segura que la que en apariencia ofrecía el texto de 1819 , al tiempo que acercarse a una forma más ortodoxa de Sistema Representativo. Eliminar resabios democráticos y contrarrestar al régimen no querido, pero posible, con atributos del régimen venerado, era la consigna: por

40 Véase Tau Anzoátegui, Víctor: Casuismo y Sistema. Indagación histórica sobre el espíritu del Derecho Indiano, Buenos Aires, 1992, págs. 97-108.

41 Foucault, M.: Las palabras..., pág. 328. 
tanto, el sistema ideado en 1826 sería consolidado en unidad de régimen; dotado de un Poder Ejecutivo vigoroso, dada su naturaleza electiva y la falta de un poder "neutro". La jefatura del Estado la ejercería un ciudadano con título de presidente, con atribuciones más amplias que su par de América del Norte y muy cercano al modelo bolivariano, aunque el cargo no sería vitalicio. El presidente era "responsable", asesorado por un Consejo de Gobierno "irresponsable", alejado del modelo ministerial y cercano a los antiguos Consejos privados de los reyes.

Los autores del Proyecto Constitucional, con rigurosos fundamentos teóricos, insertan dentro del Sistema Representativo un modelo teórico que, como lo subrayarían sus detractores por lo consignado en la Secc. III -De la forma de gobierno-, parecía sólo conciliable con la categoría Gobierno Despótico, pues regía todavía el axioma determinista que alertaba: "Territorio muy Extenso y Gobierno Consolidado asociado a Centralización espacial absoluta o limitada produce Gobierno Despótico". Sólo la regionalización espacial — federal o confederal- de un territorio extenso, conjuraba el peligro.

Dada su estructura discursiva: ¿puede ser clasificada, en términos absolutos, la Constitución de 1826 como unitaria? Creemos que no. Hacerlo sería quitarle coherencia semántica ${ }^{42}$ al núcleo del discurso producido por los constituyentes, que recepta el pensamiento de un amplio sector de las élites rioplatenses; conduciría, de suyo, a un reduccionismo que desvirtuaría la compleja trama del modelo teórico. Éste busca ser mixto, desde varios ángulos: por la combinación del paradigma británico y norteamericano; por la armonización de los principios monárquico, aristocrático y democrático; por cierta concesión hacia la descentralización espacial, sin llegar a la estructura federal.

No obstante, si bien la Comisión Constitucional buscó acercarse más que en 1819 al paradigma norteamericano, éste ocupó un lugar secundario respecto del paradigma británico, dado su pronunciado federalismo. La forma de administración federal se consideraba expresión de democracia tumultuaria; débil, además, por su estructura, aunque no se dudaba que si en los Estados Unidos había resultado una experiencia viable era porque, en rigurosa teoría, tampoco allí se trataba de un régimen puramente federal, aunque así se lo definiera.

42 Van Dijk, Teun A.: Estructuras y funciones del discurso. Una introducción interdisciplinaria a la lingüística del texto y a los estudios del discurso (1980), México, 1993, pág. 13. 
Expresión del discurso-tipo unitario, el Proyecto de la Comisión recordará que federalizar el Estado era transitar por el camino siempre sinuoso de la Democracia; amenaza latente contra la estructura mixta del Sistema Representativo; suponía olvidar que sólo las "formas mixtas [convenían] a las sociedades modernas". Aceptar la federación para un territorio extenso y en las circunstancias de despoblación en que se encontraban las provincias, era renunciar al Gobierno mixto o representativo, el cual, si bien suponía conceder un lugar al régimen federativo, nunca debía insinuarse como predominante. Los miembros de la Comisión se estremecían de sólo pensar en la existencia de pueblos o asambleas populares, pues con el "inocente designio" de lograr un mayor bien, pueden "pretender usurpar más poder que el que les conviene, sin advertir que serán la víctima de su engaño, y los agentes de tiranías individuales, cuyo poder aumentan para su propia ruina". ${ }^{43}$

Para desarmar al federalismo dispersivo de los caudillos, la Comisión contempló la necesidad de otorgar cierto poder de decisión a las provincias, a través de Consejos de Administración que velaran por la "particular felicidad" de ellas. Elegidos popularmente en número suficiente, "podrán los vocales ejercer el derecho de representar ante el presidente, o ante el mismo congreso, cuanto consideren conducente al bien de su provincia". ${ }^{44}$ En síntesis, descentralización espacial de carácter municipal como lo supone el paradigma británico.

El paradigma británico también se busca incorporar en la composición del Poder Ejecutivo, encontrándose aquí la mayor combinación de las modalidades británica y norteamericana, con predominio de la segunda. Por eso, afirma la Comisión, "nadie puede reprobar con argumentos prácticos los efectos de la unidad de un poder constitucional". No se trata de la unidad que caracteriza a los gobiernos absolutos, sino del testimonio positivo ofrecido por el gobierno de los Estados Unidos. Éste avala la necesidad de reforzar el vigor del Poder Ejecutivo, si de estado con rótulo republicano se trata. Recuérdese que el Ejecutivo británico se re-presentaba como una estructura más débil que el Legislativo, regulado el sistema por la fuerza moral del monarca. ${ }^{45}$

43 Sesión del 14 de julio de 1826. Proyecto de la Comisión..., en ACA, v. III, págs. 215 y 218.

44 Sesión del 1 de septiembre de 1826. Dictamen de la Comisión de Negocios Constitucionales sobre la Forma de gobierno. Ibídem, pág. 500.

45 Sesión del 14 de julio de 1826. Proyecto de la Comisión... Ibídem, págs. 217 y sigs. 
El Proyecto constitucional en su art. 87 -reemplazado su contenido en el texto definitivo - buscó rescatar algo del primer paradigma: la presencia de los ministros como observadores en el Congreso, aunque sin derecho a sufragio. ${ }^{46}$ También en este punto se intentaba dotar a la Constitución de un carácter mixto, que no hiciera de los ministros diputados, ni fueran facultados para sufragar en el Parlamento como en Gran Bretaña, pero que tampoco se encontraran inhabilitados para entrar en la Cámara como en Estados Unidos de América del Norte. ${ }^{47}$ "Esto es lo que tiene de ventajosa nuestra Constitución, aun con respecto a la de los Estados Unidos, porque aunque niegue el voto a los ministros no les niega la facultad de discutir las materias, y de este modo quedan deslindados los poderes", lográndose la armonía y la comunicación de éstos, afirma de Castro.

\section{Sistema Representativo: composición de la representación y sistema electoral}

Las minorías reflexivas entienden a la Representación integrada por dos Cámaras: Alta (Pares o Senadores) y Baja (Comunes, Diputados o Representantes). Sólo su existencia garantiza el funcionamiento equilibrado del Poder Legislativo, pues la Cámara Alta representa el principio aristocrático - aristocracia de sangre, de dinero o de mérito-, en cambio, es en la Cámara Baja donde tiene entrada el elemento democrático o popular; ${ }^{48}$ ella es la que define al sistema, que así concebido aleja el peligro de la Democracia pura. Como apunta de Castro, el Sistema Representativo logra conciliar la Democracia con el ejercicio no tumultuario de la soberanía. ${ }^{49}$ La existencia de una sola Cámara rompería el equilibrio que garantiza la Cámara alta, quedando el Estado a merced de las luchas entre el Ejecutivo y el Legislativo, con el peligro cierto de derivar en Despotismo. ${ }^{50}$

46 Proyecto de Constitución de la República Argentina, secc. 4. ${ }^{a}$ Del Poder Legislativo, Capítulo 5, Art. 60 y Secc. 5ta.. Del Poder Ejecutivo, Capítulo 3. De las atribuciones del Poder Ejecutivo, art. 87. Ibídem, págs. 504 y 506.

47 Sesión 25 del 14 de abril de 1825. Alocución del diputado J. V. Gómez. Ibídem, págs. 1244; 1246 y 1244

48 El Argos, n. ${ }^{\circ} 29,24$ de abril de 1824 y n. ${ }^{\circ}$ 30, 28 de abril de 1824, v. IV, págs. 140 y 143.

49 Sesión 24 del 24 de marzo de 1825, en ACA, v. I, pág. 1231.

50 Sesión del 7 de agosto de 1818. Ibídem, pág. 370. 
Tomás M. de Anchorena prescribía que el despotismo más peligroso es el del Poder Legislativo; ${ }^{51}$ sería nefasto huir del despotismo de uno solo y caer en el despotismo de tres o cuatro, apunta el diputado por Corrientes, Francisco Acosta. ${ }^{52}$ Cuando ello ocurre, una ley dictada hoy puede revocarse al día siguiente. ${ }^{53}$ Habiendo dos Cámaras, cualquier proposición queda sujeta a un examen más imparcial; su existencia da mayor estabilidad a las leyes, a la vez que amplía su respetabilidad. ${ }^{54}$ Además, la existencia de una Cámara facilita la puja de facciones y, como es natural a todo Cuerpo, resulta más fácil que una de ellas la domine. Respecto de la forma de representación, en estricta ortodoxia sólo cabe que el representante obre sin ligaduras respecto de sus representados; forma de representación individual que se impone decididamente en el paradigma norteamericano. Nada hay allí que suponga instrucciones en forma de mandato imperativo a los representantes, concepto evocador de la "democracia pura o tumultuaria” (soberanía del pueblo o de los Pueblos). Declarada la soberanía de la Nación, sólo existe una voluntad, la de ésta, que es la misma de los que están facultados para obrar en su nombre. Los diputados del Congreso, al serlo de la Nación, afirma de Castro, obran libres de instrucciones, ${ }^{55}$ mientras que para su opositor ideológico, José de Ugarteche, el poder de éstos es revocable, pues la soberanía reside en los Pueblos que no abjuraron de ella. ${ }^{56}$

El tema de si el representante es independiente o no de los representados va a encontrarse estrechamente relacionado con la orientación unitaria o federalista de los expositores; define los discursos-tipo básicos, expresión de dos concepciones ideológicas que aparecían como irreductibles. Lo cierto es que, tanto en el Congreso Constituyente de 1816 como en el de 1824 , los diputados acuden en calidad de embajadores de sus respectivas Provincias o Pueblos. Esta actitud responde a razones histórico-jurídicas, ya que producida la crisis del Imperio Español, cada entidad regional (Intendencia) reasumió la soberanía y, por tanto, se consideró independiente.

Como lo señalaran Gorriti y de Castro, existe Nación en tanto todos comparten básicamente una misma cultura, pero no en el sentido de unidad jurídico-política, pues no se rigen por una misma ley y un mismo gobier-

51 Sesión del 3, 4 y 5 de julio de 1816. Ibídem, pág. 232.

52 Sesión del 14 de julio de 1826, en ACA, v. III, pág. 227.

53 Sesión del 23 de junio de 1826. Alocución de M. A. de Castro. Ibídem, pág. 91.

54 Sesión del Congreso (1816), en ACA, v. I, pág. 370.

55 Sesión 22 del 9 de marzo de 1825. Ibídem, pág. 1.201.

56 Sesión del 5 de septiembre de 1826, en ACA, v. III, pág. 539. 
no. ${ }^{57}$ Adviértase que aquellos diputados que acudieron al Congreso de 1824-1827 y adoptaron una actitud independiente de sus representados, fueron relevados por los gobiernos provinciales; como ocurrió con los diputados cordobeses. De igual forma, cuando el Congreso constituyente de 1816-1820 consideró la propuesta de coronar como monarca del Río de la Plata al duque de Luca, el diputado Jaime Zudáñez salvó su voto expresando que no tenía facultades para contrariar la voluntad de su Provincia en favor del Gobierno Republicano, "manifestada en las Instrucciones a sus Diputados para la Asamblea General del Estado". ${ }^{58}$

Respecto del sistema electoral sustentado en el "ciudadano-átomo", éste hace a la naturaleza misma del Sistema Representativo Ortodoxo, cuya modalidad reemplaza al sistema corporativo o estamental por el individual. Tras la revolución norteamericana y francesa comienza a reglamentarse la forma de elección que se plasmara en el régimen censitario, acompañado de una igualdad formal de los ciudadanos, autorizados a votar en virtud de determinados criterios de propiedad o renta. Se parte del principio, luego desarrollado por Benjamín Constant, de que la igualdad tiene su límite en la capacidad y, por tanto, un gobierno representativo es el gobierno de la razón del pueblo y no el de la parte ciega e irreflexiva.

Interpretado el régimen electoral en estos términos, la voz democracia pierde su carga semántica original para hacerse sustituto léxico de aristocracia. De forma tal que, en términos de ortodoxia liberal, un régimen será más representativo en la medida que el componente aristocrático se imponga de alguna manera en ambas Cámaras. Ejemplos elocuentes son las Constituciones de 1819 y 1826, las cuales se complementan, en la parte pertinente a la representación, y constituyen una relevante expresión de la naturaleza del Gobierno Mixto. ${ }^{59}$

En 1819, los redactores del Proyecto constitucional afirmarán que, integrado el Senado con ciudadanos distinguidos, ya por serlo de la clase militar o eclesiástica, ya por sus riquezas y talentos, se aprovecha lo útil de la aristocracia, mientras que, reservando la Cámara de Representantes a los ciudadanos sin fueros o comunes, se salva el carácter democrático, evitán-

57 Sesión 28 del 28 de abril de 1825. Alocución del diputado M. A. de Castro y Sesión 32 del 4 de mayo de 1825. Alocución del diputado J. I. de Gorriti, en ACA, v. I, págs. 1284 y 1325.

58 Sesión Secreta del 20 de noviembre de 1819. Ibídem, pág. 590.

59 A. Sáenz, después de definir esta categoría, explica distintos modelos que conducen, por la disposición de los elementos constitutivos, hacia una Monarquía Constitucional o hacia una República (Instituciones elementales sobre el Derecho Natural y de Gentes. Curso dictado en la Universidad de Buenos Aires en los años 1822-1823, Buenos Aires, 1939, págs. 110 y 115 y sigs.). 
dose a la Nación las borrascas de la simple democracia con su secuela de arbitrariedad y despotismo, dos lexemas identificados desde el siglo XVIII. Los autores del Proyecto, atendiendo a aspectos sociológicos y culturales de los Pueblos y, conociendo que en la región éstos estaban habituados a respetar ciertas clases que poseían fueros e inmunidades, no quisieron introducir innovaciones. ${ }^{60}$

En última instancia, toda Constitución de un Pueblo libre es el "pacto social que determina la forma de gobierno" de un Estado, "asegura la libertad del ciudadano y abre los cimientos del reposo publico". ${ }^{61}$ Ella sería efímera si se desconoce la realidad social, y llevaría a "incurrir en la temeridad de algunos legisladores" que, dejándose llevar por sistemas especulativos, buscan igualarlo todo desconociendo las jerarquías que hacen a la naturaleza de las cosas y constituyen el basamento de una sociedad. De allí que se haya pensado en un Senado que abra las puertas "a las clases y ciudadanos distinguidos". Ellos gozan de rentas que influyen "sobre la clase común o laboriosa"; dependen del Poder Ejecutivo en sus ascensos, inclinándolos hacia la autoridad y, por tanto, permiten "balancear y contener la popularidad de la Cámara" de la clase común.

El tiempo de permanencia de los senadores en el cargo requiere una solución que debe apartarse del paradigma británico, en tanto la Cámara de los Pares se compone de nobles temporales y espirituales cuyo cargo es hereditario, y la Constitución de 1819 daba forma al Senado con figuras prominentes pero que no poseían grado de nobleza. Una solución alternativa se encuentra en permitir a los senadores una permanencia más prolongada en sus funciones (12 años), determinada por "la experiencia de sus miembros y la respetabilidad del Cuerpo", pero no se inclinan los constituyentes por la perpetuidad, pues ello "pone en riesgo la parte democrática de la Constitución" y facilita el camino regresivo: democracia, aristocracia, oligarquía y despotismo. De allí que si en estados como Gran Bretaña la existencia de un Senado perpetuo garantiza el equilibrio del sistema político, no se podían olvidar los movimientos revolucionarios a que dio lugar su existencia en Roma y en Creta. ${ }^{62}$

Respecto de la Constitución de 1826, al discutirse el art.6. ${ }^{\circ}$, inc.6. del Proyecto Constitucional, que suspendía la ciudadanía a los peones y jorna-

60 Sesión del 31 de agosto de 1818. Ibídem, págs. 376 y sigs.

61 Funes, G.: Manifiesto..., en ACA, v. VI - 2. ${ }^{a}$ parte-, pág. 724.

62 Sesión del 31 de agosto de 1818. Ibídem, págs. 376 y sigs.; 381 y sigs..; 378-382. 
leros, se pregunta de Castro: "¿Quién ha dicho que todos deben ejercer el derecho de sufragio?". Jamás podía concedérsele a quienes eran económica y culturalmente dependientes, pues no podía esperarse de ellos juicios políticos libres; en consecuencia sólo debía reconocerse el derecho de sufragio a los ciudadanos susceptibles de resistir las presiones sociales o económicas y capaces de asumir la responsabilidad pública de sus preferencias el día de la elección. No puede votar quien no tiene opinión formada, encontrándose el doméstico a sueldo en una condición cercana a la del siervo. Por ello, las constituciones más libres exigen libertad en el individuo que haya de sufragar. Extender a tanto la elección destruiría el Sistema Representativo. ${ }^{63}$

Se observará entonces que, para la integración de la Cámara de Representantes, se hace una trasposición de términos, pues su integración busca convocar a la parte más sana de la población, convirtiendo la Cámara democrática en verdaderamente aristocrática; el modelo quedaba a salvo, pues el acto de votar era de naturaleza democrática, en tanto se convocaba al pueblo más allá de que éste comprendiera sólo a acotados sectores de la opinión pública o voluntad general, sintagma este último expurgado de connotaciones roussonianas, aun en el discurso de los federales doctrinarios. ${ }^{64}$

En un Sistema Representativo que invierte los términos de delegación de la soberanía, interesa particularmente la composición del Poder Legislativo, por constituir el motor que lo activa. La soberanía, ejercida por representantes independientes en sus decisiones, reconoce como única fuente de legitimidad política una Constitución — construcción normativa racional o histórica-. ${ }^{65}$ Ésta reserva a la autoridad ejecutiva tradicional (rey) un lugar meramente residual. Pero, neutralizada la prototípica autoridad animadora del cuerpo social (el rey) y las fuerzas sociales que constituían los pilares básicos de la Monarquía, le urgía al principismo liberal impedir cualquier radicalización del sistema. Dentro de este contexto teórico, que en Iberoamérica debía convivir con una situación atípica derivada de su proceso emancipador, las minorías reflexivas rioplatenses advirtieron la necesidad de restringir la expresión democrática, latitud que variaba según fuera el discurso unitario o federal.

63 Sesión del 25 de septiembre de 1826. Ibídem, págs. 741 y 734.

64 Véase este matiz roussoniano en Sesión del 26 de junio de 1825. Alocución de Manuel Dorrego. Ibídem, págs. 24 y sigs.

65 García Pelayo, M.: Derecho..., págs. 34-41. 
Imperativo categórico para los unitarios era alejar aún de la Cámara Baja todo grupo sospechoso de "espartanismo", ${ }^{66}$ de ideas demagógicas o despóticas, de actitudes tumultuarias o de pura democracia, según los sintagmas en boga. En un sistema puramente electivo, se imponía crear distintos grados de aristocracia: la opinión publica dominaría y, entonces, la plebe (integra un campo léxico cuyo eje es multitud), siempre propensa a dejarse envolver por caciques o caudillos, ya no sería motivo de preocupación. De Castro inquiría, en relación con el contenido del art.6. ${ }^{\circ}$, inc. 6: “¿Déseme una Constitución por libre y republicana que sea que no pida en los hombres para la calidad de representantes un haber u oficio, que les de una renta anual?", acerca de lo cual, Manuel Dorrego, portavoz de la oposición, advertía que, de una elección así concebida, resultaría el dominio de la aristocracia más terrible cual es la aristocracia de dinero.

De Castro había señalado la peligrosidad "de las aristocracias hereditarias monárquicas porque se oponían a las leyes y a un sistema libre", táctica legislativa que buscaba, frente a la oposición, justificar a la aristocracia autóctona que, por su naturaleza, era claramente una oligarquía. La aristocracia, como opuesta a las leyes y a un sistema libre, constituía un amplio estereotipo léxico, referido a un Oriente difuso y a un Occidente atemporal, que excluía automáticamente al admirable "País Libre", Gran Bretaña, cuya Cámara de Pares garantizaba la armonía de la balanza constitucional.

Pedro F. Sáenz de Cavia, atento a las palabras de de Castro, responde con un estereotipo complementario al afirmar que la exclusión de peones y domésticos sería natural en un Estado monárquico absoluto. En su intento por jaquear el discurso opositor, Valentín Gómez desnuda parte del tejido ideológico rioplatense, señalando que, al discutirse el art. $6 .^{\circ}$, inc. 6 , se tuvo presente la situación de las provincias y lo que siempre había sido en ellas costumbre, razón por la cual se eludió cualquier forma de elección absolutamente popular y directa. ${ }^{67}$

\section{Sistema Representativo: caracterización}

A través del recorrido realizado pudimos comprobar los desplazamientos discursivos, producida la quiebra de la unidad nacional en Cepeda. Se advierte entonces que, sobre todo los sectores enrolados en la República

66 "Espartanismo" fue una voz empleada por M. Dorrego, interpretada por M. A. de Castro como sinónimo de Despotismo o Democracia tumultuaria. Véase Sesión del 3 de octubre de 1826, en ACA, v. III, pág. 921.

67 Sesión del 25 de septiembre de 1826. Alocuciones de Castro, Dorrego, Sáenz de Cavia y Gómez. Ibídem, págs. 739; 735; 738; 743; 746. 
consolidada en unidad de régimen, insistirán en la caracterización de un paradigma que estiman la Provincia de Buenos Aires ha comenzado a implementar a partir del año '20; modelo que deberán imitar las demás provincias $^{68}$ en la medida que quieran avanzar por el camino de la civilización, dejando atrás la barbarie inveterada. Tal es el meollo del discurso unitario, por otra parte, el doctrinariamente más rico.

Un enfoque conceptualizante de la historiografía resulta el intento de alejarla de una visión meramente impresionista, procediendo para ello a forjar conceptos. Como este ensayo es fundamentalmente el de ese intento conceptualizador aplicado a una determinada categoría político-institucional, quiere este acápite final aparecer como una suerte de síntesis de la labor decodificadora, compendiando en cuatro grandes ejes los caracteres con que las minorías reflexivas rioplatenses se re-presentan al Sistema Representativo.

\section{Sistema electivo y Asambleas Representativas del pueblo}

El nuevo concepto de Asambleas Representativas es el motor del Sistema Representativo, en tanto el régimen de corporaciones - luego de 1820, tanto para el sector denominado unitario como para el federal doctrinario y, a la luz del Senado corporativo contemplado por la Constitución de 1819-, se convertirá en objeto de agrias críticas. Las corporaciones aparecerán como eje de un campo léxico identificado con las "épocas de confusión y de error, ligadas a prestigios y autoridades falsas" ${ }^{69}$ El Sistema Representativo era el fruto de la razón; de allí que hablar de una nación que se decidiera por el funcionamiento de las Asambleas de Representantes era hacerlo de un pueblo dotado de Gobierno libre. ${ }^{70}$ Éste fue uno de los sintagmas más difundidos para hablar de Gobierno representativo, pero su campo léxico lo integran otros como: Gobierno regular, Gobierno constituido ${ }^{71}$ Gobierno de Instituciones libres, ${ }^{72}$ Gobierno racional y moderado, ${ }^{73}$ propio de un país libre, como así llama El Argos a Buenos Aires. ${ }^{74}$

68 "Entre Ríos", El Correo de las Provincias, n. ${ }^{\circ}$. 11, 27 de febrero de 1823, t. X, pág. 9124.

69 Véase El Argos, n. ${ }^{\circ}$ 81, 26 de octubre de 1822, v. II, pág. 332; n. ${ }^{\circ} 83,2$ de noviembre de 1822, v. II, pág. 337; n. ${ }^{\circ} 79,19$ de octubre de 1822, v. II, págs. 324-s.; n. ${ }^{\circ} 95,20$ de noviembre de 1824 , v. IV, pág. 423. También El Centinela, n. ${ }^{\circ}$ 12, 13 de octubre de 1822, t. IX -1. a parte-, pág. 8095.

70 Sesión del 14 de julio de 1826. Proyecto de la Comisión de Negocios Constitucionales, en ACA, v. III, pág. 215.

71 El Argos, n. ${ }^{\circ} 17,17$ de marzo de 1824, v. IV, pág. 87 y n. ${ }^{\circ} 16,13$ de marzo de 1824, v. IV, pág. 86.

72 El Argos, n. ${ }^{\circ}$ 29, 24 de abril de 1824, v. IV, pág. 139.

73 La Crónica Argentina, n. ${ }^{\circ}$ 19, 30 de septiembre de 1816, t. VII, pág. 6324.

74 El Argos, n. ${ }^{\circ} 78,16$ de octubre de 1822, v. II, pág. 320. 
El discurso subraya las virtudes de la República clásica ${ }^{75}$ y las trasvasa a la naturaleza del Sistema representativo y al carácter electivo que lo define ${ }^{76}$ De no mediar mención explícita de la modalidad gubernativa, la voz República debe entenderse como sinónimo de Sistema Representativo. ${ }^{77}$ En otras palabras, con una u otra denominación se apunta al único gobierno donde impera la ley; ${ }^{78}$ es el sistema de la ley. De allí que ya no importe cuál sea el modo de organización del gobierno. ${ }^{79}$

Para la concepción liberal racionalista, la legitimidad de la ley estará dada por el órgano del cual emana — las Asambleas legislativas-, por las formalidades externas, por su carácter coactivo, aun cuando dicha legislación resulte contraria a los intereses generales. Esta expresión del sistema electivo, traducida en la voz de los legisladores, fue el canal por medio del cual la ley adquirió el carácter omnipotente al que se refiere una figura reverencial en el ámbito rioplatense: Lázaro Carnot. Puede afirmarse que la voluntad del legislador se impondrá "en detrimento de la labor creadora del jurista, de la costumbre y de las aspiraciones de la comunidad". ${ }^{80}$

Concebido en su forma ortodoxa, el Sistema Representativo verá en las tradiciones de los pueblos rémoras que será necesario remover lentamente para que se imponga la luz de la razón. Para instaurarlo, habrá que "desarraigar hábitos perniciosos" y enfrentarse "con pasiones encarnizadas". ${ }^{81}$

\section{Gobierno Mixto: la balanza constitucional}

El discurso-tipo conceptualiza la división del poder como el pivote de la forma de gobierno representativo, lo que supone la independencia de las ramas del poder, pero también su interrelación y el contrapeso necesario. ${ }^{82}$ Por su complejo entramado, el Sistema Representativo sólo podrá impo-

75 El Centinela, n. ${ }^{\circ} 68,9$ de noviembre de 1823 , t. IX -2. ${ }^{a}$ parte-, pág. 8976.

76 Sesión 25 del 14 de abril de 1825. Alocución de J. I. de Gorriti, en E. Ravignani, comp.: Asambleas..., v. I, pág. 1247.

77 "El Sistema Representativo es básicamente un régimen republicano", afirma el abate de Pradt. (El Censor, n. ${ }^{\circ} 38,16$ de mayo de 1816, t. VIII, pág. 6747).

78 Sesión del 3 de octubre de 1826. Alocución de M.A. de Castro, en ACA, v. III, pág. 919.

79 El Argos, n. ${ }^{\circ} 34,12$ de mayo de 1824, v. IV, pág. 164.

80 Tau Anzoátegui, V.: “¿Qué es la ley?”(1984), en V. Tau Anzoátegui: La Ley en América Hispana. Del Descubrimiento a la Emancipación, Buenos Aires, 1992, pág. 436. Véase págs. 433-437.

81 El Centinela, n. $^{\circ} 42,11$ de mayo de 1823 , t. IX -2. ${ }^{a}$ parte-, págs. 8598 Y 8597.

82 Véase Sesión del 14 de julio de 1826. Proyecto de la Comisión de Negocios Constitucionales, en ACA, v. III, pág. 215. 
nerse efectivamente en épocas de madurez política ${ }^{83}$ pues, como ocurre con toda ciencia, se perfecciona con la experiencia y la meditación. ${ }^{84}$

Referir al deslinde de poderes, afirma Vicente Pazos Silva, es hacerlo de potencias secundarias, pues las potencias primarias con que se construye también el gobierno representativo, no son otras que las formas puras de la taxonomía aristotélica. Potencias primarias y secundarias conforman el llamado Gobierno mixto, sobre cuya estructura se levanta la categoría Sistema Representativo, pero los verdaderos poderes (Potencias primarias) de que se habla en la Constitución inglesa son el Rey, la Nobleza y el Pueblo; ellos constituyen "las bases o matriz de que parte su gallardía original, su consistencia, su majestad". ${ }^{85}$

Como apunta el deán Funes, en América el Gobierno es mixto, pues "su organización social algo tiene de democracia [...], de aristocracia electiva [y] de Monarquía Constitucional". ${ }^{86}$ En el Manifiesto explicativo de la Constitución de 1819, señala que ésta adoptaba la forma mixta de gobierno, elucidando que - como lo haría la Comisión constituyente en relación con el texto de 1826 - tal constitución era un estatuto que se acercaba a la perfección, pues no era "ni la democracia fogosa de Atenas [...], ni la aristocracia patricia de Roma, ni el gobierno absoluto de Rusia, ni el despotismo de la Turquía, ni la federación complicada de algunos estados". ${ }^{87}$

Según afirma Carnot, Monarquía Constitucional y República equilibrada tienen muchos puntos comunes: ${ }^{88}$ ¿Acaso hay contrariedad en ellas?", pregunta Funes y, siguiendo a "Desttut de Tracy", señala que resulta impro-

83 El Argos, n. ${ }^{\circ} 23,11$ de septiembre de 1821, v. I, pág. 140.

84 "Caracteres de una justa libertad y de un poder legítimo. De la célebre Memoria de Lázaro Carnot dirigida a Luis XVIII en julio de 1814 -Continuación-", El Censor, n. ${ }^{\circ}$ 137, 2 de mayo de 1818, t. VIII, pág. 7375.

85 “Observación”, La Crónica Argentina, n. ${ }^{\circ}$ 31, 14 de diciembre de 1816, t. VII, pág. 6411. Similar apreciación le merece el tema a los redactores de La Abeja Argentina [entre otros Felipe Senillosa, J. S. de Agüero, Manuel Moreno y J. V. Gómez] que, en relación con la "balanza de poderes, tan alabada por su prestigio en la Constitución inglesa", afirman: que ella no existe "entre los poderes sino entre órdenes del Estado, [entre] tres fuerzas distintas[...] el rey, los barones y el pueblo". ("La Balanza de los Poderes", La Abeja Argentina (1822-1823). Reimpresión facsimilar. Semanario de Buenos Aires, n. ${ }^{\circ}$ 6, 15 de agosto de 1822, en BM, t. VI, pág. 5406).

86 "Janeiro. Contestación al artículo del diario brasilero", El Argos, n. " 40, 17 de mayo de 1823, v. III, pág. 164.

87 Funes, G.: Manifiesto..., en ACA, t. VI -2. ${ }^{a}$ parte-, pág. 725. Véase la reproducción final en: Sesión del 14 de julio de 1826. Proyecto de la Comisión de Negocios Constitucionales, en ACA, v. III, pág. 215.

88 "Caracteres de una justa libertad y de un poder legítimo. De la célebre Memoria de L. Carnot dirigida a Luis XVIII en julio de 1814 —Continuación”, El Censor, n. ${ }^{\circ}$ 137, 2 de mayo de 1818, t. VIII, pág. 7375. 
pio emplear "la clasificación de republicano [...] para indicar oposición con la de monárquico". ${ }^{89}$ Para El Argos, los elementos que conforman el Gobierno mixto lo identifican con el gobierno de Pueblos soberanos, y resulta toda una definición de "las instituciones del siglo a que pertenecemos". ${ }^{90}$

Entendido el Gobierno Mixto como régimen de equilibrio de fuerzas antagónicas, éste se daría entre las potencias primeras, pero además y, por su dependencia de éstas, entre los poderes ejecutivo y legislativo. El equilibrio se identifica con la imagen de la balanza constitucional, que ofrece dos interpretaciones en relación con la entidad encargada de constituirse en su fiel. Partiendo del paradigma británico se observará que, para algunos sectores de las minorías, el fiel de la balanza constitucional estaría dado por la Cámara de Senadores - la Nobleza según la teoría de Montesquieu-, y así lo refleja tanto la Constitución de 1819 como la de 1826; para otros, el equilibrio surgiría del balanceo entre dos poderes fuertes: el Ejecutivo y el Legislativo. El discurso-tipo de los constituyentes de 1819 y de aquellos que en 1826 eran partidarios de un régimen consolidado, coincidía en afirmar que sólo el Senado lograría impedir el choque entre "dos fuerzas que tienen una dirección encontrada": el Poder Ejecutivo y la Cámara de Representantes, pues permitiría equilibrar su potencia. ${ }^{91}$ El Senado debe ser un cuerpo mediador entre el "poder armado" — ejecutivo— y "el poder popular" - Cámara de Representantes—..$^{2}$

En 1820, los redactores de La Estrella del Sud ofrecen otra interpretación de la balanza constitucional. De sus reflexiones surge que la forma de gobierno representativa requerirá de elementos niveladores diversos, de acuerdo con la modalidad gubernativa adoptada. Consideran que constituyó un error de los congresales haber hecho del Senado el fiel de la balanza constitucional, pues éste sólo puede ser apropiado para los Estados de Europa, donde existe un fiel natural, los nobles, que ponen en equilibrio a "masas de distinto peso: pueblo por una parte; hombres de sangre real [...] de la otra". Sostienen los redactores que jamás podría implementarse en el Plata esa "concepción sublime de la política moderna" que se da en la Monarquía Constitucional, pues en ella el Senado puede contrabalancear,

89 "Janeiro - Contestación al artículo del diario brasilero-_, El Argos, n. ${ }^{\circ} 40,17$ de mayo de 1823, v. III, págs. 164-s..

90 El Argos, n. ${ }^{\circ} 84,16$ de octubre de 1824 y n. ${ }^{\circ}$ 94, 17 de noviembre de 1824, v. IV, pág. 381 y pág. 419.

91 Sesión del 7 de agosto de 1818, en ACA, v. I, pág. 370.

92 Sesión de 1 de septiembre de 1826. Dictamen de la Comisión de Negocios Constitucionales relativo al Proyecto de Constitución, en ACA, v. III, pág. 498. 
al gozar del prestigio que le dieron los siglos, lo cual falta "en los pueblos nuestros", donde no existen distinciones tan marcadas. ${ }^{93}$

El Censor, parafraseando a John Adams, alude a la solución más adecuada a un Estado representativo bajo la modalidad de República. Adams reflexionará sobre el Gobierno Mixto a la luz de la Constitución de 1787, con la finalidad de obtener un amplio protagonismo del Ejecutivo. Construirá su discurso refiriéndose a las luchas entre "facciones aristocráticas y democráticas" en las pólis griegas, afirmando que tal situación pudo darse en tanto ningún "partido pensó en adoptar una balanza constitucional, creando un ejecutivo con igual poder para [contrabalancearlas]". La balanza constitucional debería conformarse con dos platillos de igual peso: Poder Ejecutivo y Legislativo, pues sólo el mutuo equilibrio permite la armonía política. ${ }^{94}$

Los criterios divergentes respecto del mecanismo de la balanza constitucional, se relacionan con la incidencia que dentro del Sistema Representativo se otorga al Poder Legislativo. En la región rioplatense, los portavoces más ortodoxos del liberalismo consideran que la realidad hispano-criolla sólo permite privilegiar la fuerza del Legislativo mediando la ausencia de oposición en las Cámaras. ${ }^{95}$ Como parten del supuesto de que el Poder Legislativo sabrá interpretar fielmente las intenciones del Ejecutivo, éste aparecerá como aplicado ejecutor de la obra legislativa que, en último término, será la suya. El esquema planteado por Adams, no obstante, también encontrará cabida en este sector, como lo demuestran los editoriales de El Correo de las Provincias. ${ }^{96}$ Entre quienes abogan por el sistema de administración federal se privilegia, sin ambages, la fuerza del Ejecutivo; de allí la admiración por el modelo bolivariano. ${ }^{97}$

En lo que no existe divergencia es en la necesidad de que el Poder Legislativo se integre con dos Cámaras, conciliando el principio democrático de la Cámara de Representantes con el principio aristocrático de la

93 La Estrella del Sud. Reimpresión facsimilar. Semanario de Buenos Aires, n. ${ }^{\circ}$ 5, 22 de septiembre de 1820 , en BM, t. IX - $1 .^{\text {a }}$ parte—, pág. 7880.

94 "Examen del Sistema Federativo. Efectos del federalismo en las repúblicas antiguas". El Censor, n. ${ }^{\circ} 99,7$ de agosto de 1817 , t. VIII, pág. 7146.

95 Es al Poder Legislativo - en referencia concreta a la Sala de Representantes de Buenos Aires- a quien "toca llenar la prosperidad" (El Argos, n. ${ }^{\circ}$ 99, 4 de diciembre de 1824, v. IV, pág. 447).

96 El Correo de las Provincias, al referirse al Poder Legislativo, especifica que no debe ser soberano, pues la representación recae en el Poder Ejecutivo y en el Legislativo a la vez. (N. ${ }^{\circ} 8,6$ de febrero de 1823 , t. X, pág. 9190 )

97 Véase Biblioteca Nacional - Buenos Aires_, Sección Hemeroteca - Sala de ReservadosEl Tribuno, n. ${ }^{\circ}$ 4, 22 de octubre de 1826, t. I, págs. 42 y 50; n. ${ }^{\circ}$ 5, 25 de octubre de 1826, t. I, págs. 55 y sigs. 
Cámara de Senadores. ${ }^{98}$ Es este equilibrio el que decide el carácter que adoptan las leyes sancionadas por el Congreso de Estados Unidos: sabias, libres y filantrópicas; ${ }^{99}$ armonía, por otra parte, posible, en tanto existen "reputaciones patricias". ${ }^{100}$

\section{Opinión pública y publicidad de los actos de gobierno}

En el Manifiesto con que debe acompañarse a los Pueblos la Constitución de 1826, se caracteriza al Sistema Representativo afirmando: "Es libre y feliz un gobierno que deriva sus poderes de la voluntad del pueblo [...] y que respeta inviolablemente los derechos del hombre". ${ }^{101}$ Será su lema, como afirma el deán Funes, "trabajar todo para el pueblo, pero nada por el pueblo"102 y tal logro ocurre, acota Sáenz de Cavia, porque las formas mixtas sustentan el Sistema Representativo; por "la delegación de los poderes públicos [...] sin los inconvenientes que [...] perturbaron la tranquilidad de las Repúblicas antiguas".

De allí que el Sistema Representativo requiera de la opinión pública virtudes eminentes, pues en ella descansa la elección de los magistrados; ${ }^{103}$ un Sistema al que siempre se opondrán aquellos que no quieran abandonar la educación anterior o, lo que es lo mismo, los déspotas. ${ }^{104}$

Sáenz de Cavia apunta que es ley del Sistema Representativo el "querer común y la opinión general", ${ }^{105}$ para señalar en otro momento, en relación con la República Representativa Federal, que se encuentra legitimada por la opinión y voluntad general, ${ }^{106}$ sintagmas convertidos en sinónimos dentro del nuevo marco ideológico, pues ahora hablar de voluntad general es hacerlo de razón del pueblo, quedando conjurado el fantasma de la Democracia pura.

98 El Argos, n. ${ }^{o}$ 30, 28 de abril de 1824, v. IV, pág. 143. Manuel Dorrego, parafraseando a Rousseau y su concepto de Democracia, afirma: "Solamente un país de ángeles puede regirse en la parte legislativa por una sola Cámara". ("Segunda alocución del Señor Dorrego, Octubre 2 de 1826", El Tribuno (1826-1827), n. ${ }^{\circ}$ 3, 18 de octubre de 1826, t. I, pág. 34).

99 Ibídem, n. ${ }^{\circ}$ 40, 1 de junio de 1824, v. IV, pág. 189.

100 “Alocución del Gobernador de San Juan”, El Argos, n. ${ }^{119,} 5$ de febrero de 1825, v. V, pág. 47.

101 Acta del 5 de diciembre de 1826, en E. Ravignani, comp.: Asambleas..., v. III, pág. 1176.

102 Funes, G.: Manifiesto..., Ibídem, v. VI -2. ${ }^{\text {a }}$ parte-, pág. 722.

103 El Centinela, n. $^{\text {o } 72, ~} 7$ de diciembre de 1823, t. IX - 2. a parte-, págs. 9025 y 9032.

104 Ibídem.

105 "Exterior. Perú y Bolivia", El Tribuno, n. ${ }^{\text {52 }} 7$ de abril de 1827, t. I, pág. 740.

106 El Tribuno, n. ${ }^{\circ} 5,5$ de mayo de 1827, t. II, pág. 69. 
El Sistema Representativo se adoptó como medio para que "se manifieste la voluntad general", evitando así el "acto tumultuoso", afirma Manuel Dorrego ${ }^{107}$ pues, "en los sistemas representativos la excelencia de las leyes [resulta] de la opinión pública; expresión de la voluntad general", acota Gorriti. ${ }^{108}$

¿Quiénes constituyen la opinión pública? Llamada genéricamente "pueblo" o "parte sana y útil"109 —Daunou la identifica con Nación—, ${ }^{110}$ refiere a aristocracia reducida, en los países cuya forma representativa no adopta la modalidad monárquico constitucional, a serlo solamente de mérito. ${ }^{111} \mathrm{La}$ integran hombres de letras, empleados, capitalistas, artistas, hombres industriosos. ${ }^{112}$ Conforma la moral pública, y es resultado "de los escritos, de las Instituciones, de la Civilización. Propia de las naciones cultas de Europa". ${ }^{113}$ Frente a la opinión pública o razón del pueblo, encontramos la multitud, ${ }^{114}$ eje de un campo léxico integrado por: votos ciegos, ${ }^{115}$ bajo pueblo, ${ }^{116}$ plebe, ${ }^{117}$ multitud imbécil. ${ }^{118}$

Castro, al referir al sistema electoral, explica quiénes deben quedar excluidos, pues "por democrático que sea el gobierno republicano, nunca puede comprender a aquellos que no tienen todavía una voluntad bastante ilustrada por la razón, o que tienen una voluntad sometida a la voluntad de otros" ${ }^{119}$ En el Sistema Representativo no hay lugar para la voluntad colectiva, caprichosa, irracional; para los votos ciegos, como apuntaba El Nacional.

107 Sesión del 16 de junio de 1826. Alocución de M. Dorrego, en E. Ravignani, comp.: Asambleas..., v. III, pág. 25.

108 Sesión del 3 de marzo de 1826. Alocución de J. I. de Gorriti. Ibídem, v. II, pág. 856.

109 "Legislatura Nacional. Elecciones", El Nacional, n. 3 6 de enero de 1825, t. X, págs. 9320s.; n. ${ }^{\circ}$ 14, 24 de marzo de 1825, t. X, págs. 9451-s..

110 Daunou, P. C. F.: Ensayo..., pág. 108. Daunou distingue además entre opinión pública y opinión popular (Ibídem, págs. 43-45).

111 Véase Sesión del 31 de agosto de 1818, en ACA, v. I, págs. 376 y sigs.; Sesión del 10 de octubre de 1826. Alocución de M. A. de Castro, en ACA, v. III, pág. 1024; El Nacional, n. ${ }^{\circ}$ 3, 6 de enero de 1825 , t. X, pág. 9452 .

112 "Elecciones", El Nacional, n. ${ }^{\circ}$ 14, 24 de marzo de 1825, t. X, pág. 9452.

113 La Abeja Argentina, n. ${ }^{\circ}$ 7, 15 de octubre de 1822, t. VI, pág. 5429.

114 El Nacional, n. ${ }^{\circ}$ 3, 6 de enero de 1825, t. X, pág. 9321.

115 Ibídem.

116 "Ideas extractadas de un papel impreso en París en 1814", El Censor, n. ${ }^{\circ} 35,25$ de abril de 1816, t. VIII, pág. 6719; "El Estado Nuevo de las Naciones. Examen de la obra del abate de Pradt", n. ${ }^{42}$, 13 de junio de 1816, t. VIII, pág. 6771; El Nacional, n. ${ }^{\circ}$ 15, 31 de marzo de 1825, t. X, págs. 9460-s.. Véase también "Sesión del 30 de abril de 1825. Alocución de M. A. de Castro", en ACA, v. III, pág. 1285.

117 Véase sobre diferencias entre opinión pública y plebe: El Argos, n. ${ }^{\circ} 193,5$ de octubre de 1825 , v. V, pág. 341.

118 “Alocución de Sáenz de Cavia”, El Tribuno, n. ${ }^{2}$ 2, 15 de octubre de 1826, t. I, pág. 14.

119 Sesión del 3 de marzo de 1826. Alocución de M. A. de Castro, en ACA, v. II, pág. 984. 
De allí que la opinión pública deba proponer reformas en orden a la libertad, justicia y razón. Ella, la 'razón', determinará el grado de libertad. ${ }^{20}$

La forma de gobierno representativa, como gobierno racional, requiere de la publicidad de los actos del Poder Ejecutivo, la cual reemplaza al juicio de residencia, característica de un Gobierno despótico. ${ }^{121}$ La publicidad es "el principio vital de todo Sistema Representativo"122 pues ilustra a la opinión pública sobre la lealtad de sus representantes. ${ }^{123}$

\section{El principio de virtud y la amplitud de su micro-campo ${ }^{124}$ léxico}

El Sistema Representativo, en tanto de naturaleza republicana, absorbe las virtudes cívicas que tradicionalmente se consideraban inseparables de las Repúblicas de Esparta, de Atenas y de Roma; a saber, el "amor a la Patria, desinterés, sobriedad, firmeza, valor, heroicidad". ${ }^{125}$

En este sentido Lázaro Carnot sostiene que, para que fructifique el sistema representativo, debe imponerse el amor a la patria, siendo necesario para ello crear el espíritu nacional. Camilo Henríquez, que parafrasea a Carnot, endereza su discurso hacia la realidad rioplatense y, después de resaltar el desapego que observa entre quienes lo rodean respecto de la salud y gloria del país, afirma que "si no fuese por el testimonio de la historia de los pueblos antiguos, y si no viésemos que existe en alto grado en algunas naciones vecinas [Estados Unidos], tal vez no se creería la posibilidad de la existencia del amor a la patria". ${ }^{26}$

A la hora de citar arquetipos de hombres virtuosos, se impone un discurso-tipo en el que conviven dentro los prohombres norteamericanos y los de la Edad clásica. La Gaceta de Buenos Aires unirá por su virtud —sinó-

120 "Carta tal vez de Tracy o de Daunou a Rivadavia", París, 2 de diciembre de 1822, en El Correo de las Provincias, n. ${ }^{\circ}$ 15, 27 de marzo de 1823, t. X, pág. 9257. Véase P. C. F. Daunou, Ensayo..., pág. 121.

121 El Nacional, n. ${ }^{\circ}$ 2, 30 de diciembre de 1824, t. X, págs. 9306-s.

122 "El Tribuno a El Mensajero Argentino", El Tribuno, n. ${ }^{\circ}$ 9, 19 de mayo de 1827, t. II, pág. 131.

123 El Argos, n. ${ }^{\circ}$ 179, 20 de agosto de 1825, v. V, pág. 283.

124 Constituyen un "MICRO-CAMPO", el conjunto de lexemas o sintagmas que se incluyen "en un campo de orden superior"; por ejemplo, en el tema aquí estudiado, el campo de orden superior es el sintagma Sistema Representativo. (Véase Vallejos de Llobet, P.: El léxico..., pág. 16).

125 "Política", La Crónica Argentina, n. ${ }^{\circ}$ 26, 16 de noviembre de 1816, t. VII, pág. 6374. Véase "Estados Unidos -Filadelfia 24 de julio-. El Franklin de la América del Sud, o el Sr. Manuel Torres", El Argos, n. ${ }^{\circ}$ 90, 27 de noviembre de 1822, v. II, págs. 366-s..

126 "Caracteres de una justa libertad y de un poder legítimo. De la célebre Memoria de L. Carnot dirigida a Luis XVIII en julio de 1814 —Continuación”, El Censor, n. ${ }^{\circ}$ 137, 2 de mayo de 1818, t. VIII, pág. 7375. 
nimo de resolución, pureza, amor a la Patria, nobleza de sentimientos, desinterés- los nombres de Bruto y Catón a los de Franklin y Washington. ${ }^{127} \mathrm{~A}$ estas referencias, en que abundan las alocuciones de la época, se incorporarán otras que, nacidas de la fragua burguesa, ocuparán un lugar relevante junto a las prestigiosas virtudes de la Antigüedad greco-latina. En última instancia, los supuestos de las antiguas Repúblicas son también los de los gobiernos libres o representativos, y persiguen contener la anarquía, así como toda propensión al Despotismo. ${ }^{128}$

La virtud representativa-republicana se opone a la ignorancia en cualquiera de sus manifestaciones; de allí que un país libre no puede ser compatible con la existencia de privilegios exclusivos, como los de la vieja aristocracia de sangre o de cualquier otro fuero. ${ }^{129} \mathrm{La}$ moral y libertad republicanas se oponen a los despotismos, sobre todo, explica El Centinela —aludando la reforma rivadaviana—, al del clero. ${ }^{130}$ Mérito y aptitud ${ }^{131}$ se incorporan al micro-campo léxico de la virtud; aunque todavía están muy cerca de su primer significado, pudiendo incluso considerarse adjetivos de la virtud por excelencia: el amor a la patria.

Pero el micro-campo se amplía notoriamente cuando incorpora el referente de la ética capitalista y su consecuente criterio de racionalismo utilitario. En términos benthanianos, lo bueno y lo útil se hacen sinónimos. De allí entonces que hablar de felicidad y de moral será hacerlo de bienes producto del espíritu del siglo liberal e ilustrado. ${ }^{132} \mathrm{El}$ esfuerzo económico, el espíritu industrioso, el progreso, tanto en la agricultura como en la industria, serán pilares fundamentales del nuevo concepto de dignidad moral, inseparable y sólo compatible con el Sistema Representativo. ${ }^{133}$ Dentro de esa nueva ética, todo lo que no se identifique con el progreso, se considera fuera del campo de la virtud.

El Utilitarismo decreta la autonomía definitiva de lo económico, cediendo lo político la primacía al factor económico, de allí que la civili-

127 "Remitido por "El Amigo de la Virtud". Franklin y Washington", Gazeta de Buenos Aires (1810-1821). Reimpresión facsimilar. Semanario de Buenos Aires. Buenos Aires, 1910. 6 v.; n. ${ }^{\circ} 165$, 22 de marzo de 1820, v. VI, pág. 113.

128 La Abeja Argentina, n. ${ }^{\circ}$ 7, 15 de octubre de 1822, t. VI, pág. 5429.

129 Véase El Argos, n. ${ }^{\circ}$ 95, 20 de noviembre de 1824, v. IV, pág. 423.

130 El Centinela, n. ${ }^{\circ} 12,13$ de octubre de 1822, t. IX - 1. ${ }^{a}$ parte-, pág. 8095 y n. ${ }^{\circ} 72,7$ de diciembre de 1823 , t. IX -2. ${ }^{\text {a }}$ parte—, pág. 9024.

131 Ibídem, n. ${ }^{\circ} 72,7$ de diciembre de 1823, t. IX -2. ${ }^{a}$ parte-, pág. 9024.

132 La Abeja Argentina, n. ${ }^{\circ}$ 7, 15 de diciembre de 1822, t. VI, pág. 5429; El Argos, n. ${ }^{\circ} 34,12$ de mayo de 1824, v. IV, pág. 165.

133 El Argos, n. $.^{\circ} 36,19$ de mayo de 1824 y n. $^{\circ}$ 39, 29 de mayo de 1824, v. IV, págs. 171 y 185. 
zación de un pueblo se mida por la disponibilidad de crédito. ${ }^{134}$ El Nacional sostiene que es fundamental para el Sistema Representativo el orden de la Hacienda pública y el establecimiento de un adecuado sistema de crédito. ${ }^{135}$ Igualmente, en el Río de la Plata, por obra de su impronta cultural y de la singular coyuntura histórica, los supuestos últimos del Utilitarismo quedarán acotados.

El Sistema Representativo constituye el gobierno de la buena causa, de la verdad, ${ }^{136}$ el único donde puede imperar la razón y la justicia, como lo demuestra Gran Bretaña, "modelo de las costumbres, leyes y libertad". Crea el espíritu público, por medio del cual se fija la estabilidad del gobierno y se incorpora el debate. En otras palabras, la adopción de esta forma de gobierno significa el triunfo de los principios de orden y de unión. La libertad política y civil, ${ }^{137}$ la seguridad, ${ }^{138}$ la libertad de prensa como garantía de todas las otras, ${ }^{139} \mathrm{y}$ el progreso de la ilustración ${ }^{140}$ — cuyo principio básico persigue difundir la educación primaria—, ${ }^{141}$ la paz y felicidad, ${ }^{142}$ conforman otro haz de virtudes que conforman el campo léxico del Sistema Representativo. Por tanto, todo gobierno no representativo será un régimen de errores, contrastante con el régimen de razón que aglutina instituciones benéficas protectoras del comercio, las letras y la industria, tal como se observa en Buenos Aires. ${ }^{143}$

134 Ibídem, n. ${ }^{\circ} 86,23$ de octubre de 1824, v. IV, pág. 387. Véase sobre la relación "Utilidad y Justicia”: El Centinela, n. ${ }^{\circ} 42,11$ de mayo de 1823, t. IX — 2. a parte—, pág. 8598.

135 El Nacional, n. ${ }^{\circ}$ 11, 3 de marzo de 1825, t. X, pág. 9421; El Argos, n. ${ }^{\circ}$ 17, 17 de marzo de 1824, v. IV, pág. 87.

136 El Argos, n. ${ }^{\circ} 29,24$ de abril de 1824, v. IV, pág. 139.

137 Ibídem, n. ${ }^{\circ} 38,25$ de mayo de 2824 y n. ${ }^{\circ} 99,4$ de diciembre de 182448 , v. IV, págs. 182 y 444; n. ${ }^{\circ} 3,24$ de enero de 1824 , n. $^{\circ} 17,17$ de marzo de 1824 , v. IV, págs. 21 y 87; n. ${ }^{\circ} 39$ y n. ${ }^{\circ} 40$, v. IV, págs. 185 y $188 ;$ n. $^{\circ} 48,23$ de junio de 1824 , v. IV, pág. 229.

138 "Proclama del Gobierno. ¡Generoso Pueblo de Mendoza!”. Ibídem, n. ${ }^{\circ}$ 54, 17 de junio de 1824, v. IV, pág. 255.

139 El Correo de las Provincias, n. ${ }^{\circ} 16,3$ de abril de 1823, t. X, pág. 9266; El Argos, n. ${ }^{\circ} 17,17$ de marzo de 1824 , v. IV, pág. 87; n. ${ }^{\circ} 54,17$ de julio de 1824 y n. ${ }^{\circ} 76,22$ de septiembre de 1824 , v. IV, págs. 255 y 349.

140 "Proclama del gobierno. ¡Generoso Pueblo de Mendoza!”, El Argos, n. ${ }^{\circ}$ 54, 17 de junio de 1824, v. IV, pág. 255.

141 "Artículos sobre las escuelas primarias", El Censor, n. ${ }^{\circ} 84,24$ de abril de 1817; n. ${ }^{\circ} 88,22$ de mayo de 1817, t. VIII, págs. 7054 y 7078-s.; "De la influencia de los escritos luminosos sobre la suerte de la humanidad", El Censor, n. 110,23 de octubre de 1817, t. VIII, pág. 7210; "Educación", El Censor, n. ${ }^{\circ} 82,9$ de abril de 1817, t. VIII, págs. 7038-s.; "Sobre la necesidad de generalizar la educación”, El Censor, n. ${ }^{\circ} 115,27$ de noviembre de 1817, t. VIII, pág. 7242.

142 El Centinela, n. ${ }^{\circ}$ 43, 18 de mayo de 1823, t. IX -2.. parte-, pág. 8619; El Argos, n. ${ }^{\circ} 17$, 17 de marzo de 1824 y n. ${ }^{\circ} 34,12$ de mayo de 1824, v. IV, págs. 87 y 165.

143 El Correo de las Provincias, n. ${ }^{\circ}$ 9, 13 de febrero de 1823, t. X, pág. 9191. 


\section{Consideración final}

Fue éste un intento de avanzar sobre el examen de un determinado objeto de estudio desde otra perspectiva, con la intención de señalar las enormes posibilidades que la aplicación del método conceptualizante aplicado al análisis del discurso histórico abre, en función de la relectura de muchas páginas de la historia político-institucional argentina.

Lo afirmado, de manera alguna debe interpretarse en el sentido de que el método conceptualizante apresa la realidad tal cual fue en una determinada coyuntura histórica. Tal afirmación sería falaz doblemente; primero, porque el lenguaje no capta la realidad tal cual es, no está moldeado sobre ella, sino que es "el molde en que la realidad, como significativa, se da primero". Por tanto, la re-presentación que las minorías reflexivas hacen de su realidad, es inseparable de su mundo de pensamiento y de conocimientos, y el discurso que nos ofrecen es, en términos hegelianos, una "actualización" de su cultura. ${ }^{144}$ Por otra parte, conceptualizar, implica apartarse de la seducción generalizante, pero de manera alguna supone pretender eliminar la subjetividad interpretativa, pues partir de tal supuesto, quitaría rigor científico al quehacer historiográfico.

Quiso este ensayo demostrar la importancia de la Lingüística en función del análisis del discurso histórico; cómo un análisis semántico del discurso político — analizando los hilos de la trama - permite acceder a una interpretación menos lineal de los planteamientos doctrinarios de las minorías reflexivas de la época.

144 Urban, W. M.: Lenguaje y realidad, México, 1952, pág. 311. 